\title{
Article \\ Controlled Growth of Silver Oxide Nanoparticles on the Surface of Citrate Anion Intercalated Layered Double Hydroxide
}

\author{
Do-Gak Jeung ${ }^{1}$, Minseop Lee ${ }^{2}$, Seung-Min Paek ${ }^{2, *}$ and Jae-Min Oh ${ }^{1, *}$ (i) \\ 1 Department of Energy and Materials Engineering, Dongguk University-Seoul, Seoul 04620, Korea; \\ jdk941101@gmail.com \\ 2 Department of Chemistry, Kyungpook National University, Daegu 41566, Korea; shlee6697@naver.com \\ * Correspondence: smpaek@knu.ac.kr (S.-M.P.); jaemin.oh@dongguk.edu (J.-M.O.)
}

Citation: Jeung, D.-G.; Lee, M.; Paek, S.-M.; Oh, J.-M. Controlled Growth of Silver Oxide Nanoparticles on the Surface of Citrate Anion Intercalated Layered Double Hydroxide. Nanomaterials 2021, 11, 455. https:// doi.org/10.3390/nano11020455

Academic Editors: Linda J. Johnston and Alexey Pestryakov

Received: 16 December 2020

Accepted: 9 February 2021

Published: 11 February 2021

Publisher's Note: MDPI stays neutral with regard to jurisdictional claims in published maps and institutional affiliations.

\begin{abstract}
Silver oxide nanoparticles with controlled particle size were successfully obtained utilizing citrate-intercalated layered double hydroxide $(\mathrm{LDH})$ as a substrate and $\mathrm{Ag}^{+}$as a precursor. The lattice of LDH was partially dissolved during the reaction by $\mathrm{Ag}^{+}$. The released hydroxyl and citrate acted as a reactant in crystal growth and a size controlling capping agent, respectively. $\mathrm{X}$-ray diffraction, $\mathrm{X}$-ray photoelectron spectroscopy, and microscopic measurements clearly showed the development of nano-sized silver oxide particles on the LDH surface. The particle size, homogeneity and purity of silver oxide were influenced by the stoichiometric ratio of $\mathrm{Ag} / \mathrm{Al}$. At the lowest silver ratio, the particle size was the smallest, while the chemical purity was the highest. X-ray photoelectron spectroscopy and UV-vis spectroscopy results suggested that the high $\mathrm{Ag} / \mathrm{Al}$ ratio tended to produce silver oxide with a complex silver environment. The small particle size and homogeneous distribution of silver oxide showed advantages in antibacterial efficacy compared with bulk silver oxide. LDH with an appropriate ratio could be utilized as a substrate to grow silver oxide nanoparticles with controlled size with effective antibacterial performance.
\end{abstract}

Keywords: silver oxide; nanoparticle; layered double hydroxide; crystal growth; antibacterial

\section{Introduction}

Silver oxide nanoparticles (SONPs) have been widely studied due to their unique optoelectronic property and high antibacterial activities. As a semiconducting material, SONPs are known to have a wide band-gap from 1.3 to $2.4 \mathrm{eV} \mathrm{[1-3],} \mathrm{making} \mathrm{them} \mathrm{suitable}$ for photocatalytic applications, especially with the visible light-harvesting ability [4-8]. The SONP itself is utilized in photoelectrochemical or photocatalytic applications. Furthermore, SONP-based ternary oxides show fine-tuned catalytic performance as the variable coordination environments made by multi-components influence electronic structure and redox behaviour [9]. In general, SONP is synthesized through a precipitation method in which $\mathrm{Ag}^{+}(\mathrm{aq})$ is titrated with an alkaline solution, e.g., $\mathrm{NaOH}(\mathrm{aq})$, to obtain silver oxide $\left(\mathrm{Ag}_{2} \mathrm{O}\right)$ [10-12]. Although precipitation is the simplest method to produce $\mathrm{Ag}_{2} \mathrm{O}$, ion sources can remain unreacted, resulting in a non-stoichiometric problem. As an alternative for the precipitation method, a sol-gel route can be utilized [13]. As the sol-gel process involves the conversion of monomers into sol that acts as the precursor for gel, all the reactants are integrated into the final product.

The synthesis of $\mathrm{Ag}_{2} \mathrm{O}$ is fairly simple as the reaction spontaneously occurs through acid $\left(\mathrm{Ag}^{+}\right)$-base $\left(\mathrm{O}^{2-}\right)$ adduct formation. However, the fabrication of SONPs with a targeted size and shape is another challenging topic. The particle size of SONPs determines the electronic structure and it affects the interaction toward complementary catalyst or substrate, finally influencing the overall catalytic performance [14,15]. The electronic structure of semiconductors, such as SONPs, has two band structures, the valence and 
conduction bands. They are separated by a band-gap of appropriate energy. As the size of semiconducting materials reduces, the number of atomic orbitals participating in the band structure decreases, and the energy difference between the two bands increases. In addition, the particle morphology of SONPs is reported to strongly affect the antibacterial property as the release of $\mathrm{Ag}^{+}$, the antibacterial agent, was dependent on the size and shape of SONP. It was suggested by Wang et al., that different shapes of SONP particles resulted in different $\mathrm{Ag}^{+}$dissolution [16]. For example, the octahedron-shaped particles which contained $\mathrm{Ag}^{+}$ions sandwiched by two planes of $\mathrm{O}_{2}{ }^{-}$ions retarded $\mathrm{Ag}^{+}$dissolution; however, the cubic-shaped particle which had alternate stacking of $\mathrm{Ag}^{+}$ions and $\mathrm{O}_{2}{ }^{-}$ions, resulted in the facilitated release of $\mathrm{Ag}^{+}$. Furthermore, the size effect is also an important factor in antibacterial ability. As the particle size decreases, the surface area to volume ratio increases. The large specific surface area accelerated the release of $\mathrm{Ag}^{+}$ions and antibacterial effect [17]. $\mathrm{The}^{\mathrm{Ag}^{+}}$ions suppress bacteria by various routes including generation of reactive oxygen species (ROS) and direct coordination with DNA base pairs [18].

Although the particle morphology of SONP is important, difficulties in SONP synthesis with controlled particle size and homogeneity have often been reported, due to the fast precipitation reaction speed $[16,19]$. The general chemical properties of the products can be controlled by experimental parameters including reagent concentration and stoichiometry. However, their detailed physical properties, such as particle size, surface morphology and uniformity of particles, are not easily controlled by simple chemical control [20,21]. Due to these limitations, there are several proposed complementary steps in addition to the precipitation process. For instance, SONP particles with controlled size could be prepared by microwave irradiation with adjustable temperature over a short period [22]. Reverse micelle methods that limit crystal growth by preventing particle agglomeration can be adopted [23]. The electrical discharge process, which controls the generation of highly dispersed silver cations, was known to produce uniformly distributed SONPs [24]. As it is possible to micro-manipulate reaction conditions during sputtering or anodization, these methods have also been proposed to prepare homogeneous SONPs with accurately controlled coverage and loading content. Oxidation of size-controlled Ag nanoparticles as precursors was suggested as an alternative strategy to produce SONPs with high homogeneity $[25,26]$. As an oxidation process involves direct conversion, the uniform size of the precursor was maintained in SONPs.

SONPs are often combined with other components to form hybrid catalysts or effective antibacterial surface coating $[17,19,27]$. For example, SONPs hybridized with $\mathrm{ZnO}$ showed promoted interfacial electron transfer process and reduced the charge recombination, resulting in improved photocatalytic effect [19]. Due to the antibacterial property and high stability, SONPs can be utilized as an infection-free coating in medical materials [17,27]. Inspired by the hybridization strategy, we propose a methodology to prepare SONPs with controlled size through hybridization with an appropriate substrate. A similar approach was reported by Rajabi et al. [17]. They applied an ultrasonic method to develop SONPs with homogeneous particle size on fabric to produce antibacterial textile [17]. Different from the Rajabi et al., work, we are going to utilize layered double hydroxide (LDH) as a substrate to produce homogeneous SONPs. In terms of structure, LDH is composed of a positively charged mixed metal hydroxide layer $\left(\left(\mathrm{M}(\mathrm{II})_{1-\mathrm{x}} \mathrm{M}(\mathrm{III})_{\mathrm{x}}(\mathrm{OH})_{2}\right)^{\mathrm{x}+}\right)$ and electrostatically stabilized interlayer anions $[28,29]$. Due to the various combination of metals and exchangeable interlayer anions, LDHs have been extensively studied as a platform for drug reservoirs [30-32] and a supporter in the hybrid catalyst [33,34]. Recently, Chen et al., reported that $\mathrm{Ag}_{2} \mathrm{O}$ could be formed on an $\mathrm{LDH}$ surface, utilizing LDH as a crystal growth substrate [35]. They mixed $\mathrm{AgNO}_{3}$ solution with a $\mathrm{ZnAl}-\mathrm{LDH}$ suspension and $\mathrm{NaOH}$ was added to induce surface precipitation of $\mathrm{Ag}_{2} \mathrm{O}$ on the LDH surface. The LDH moiety in that report was utilized both as a substrate to grow $\mathrm{Ag}_{2} \mathrm{O}$. In this contribution, we expanded the utility of LDH not only as a substrate to grow/immobilize $\mathrm{Ag}_{2} \mathrm{O}$ but also as a source of reactant and crystal-growth-modifier. For this purpose, the interlayer space of LDH was populated with citrate anions, which would be used as a capping agent to 
stabilize the crystal growth of $\mathrm{Ag}$ [36]. At the early stage of reaction, the edge of LDH is considered to be partially dissolved by the acidity of $\mathrm{Ag}^{+}$, resulting in the release of $\mathrm{OH}^{-}$ for $\mathrm{Ag}_{2} \mathrm{O}$ precipitation. Simultaneously, the citrate moiety would be provided from LDH. It is reported that the intercalated moiety in LDH structure is released in a controlled manner due to ion exchange property and periodic molecular arrangement in the gallery space of LDH $[32,37,38]$. Typically, the citrate supply would be mediated by the following general steps: (i) citrate at the periphery of the particle is released relatively fast, and (ii) the anions inside the particles would be released in a sustained manner. In this way, citrate moiety, which acted as a size controlling capping agent, would be slowly provided during the reaction between $\mathrm{Ag}^{+}(\mathrm{aq})$ and $\mathrm{OH}^{-}$. The as-released citrate would readily cap the surface of SONP nuclei, preventing fast and random growth.

The current strategy could be realized as follows. Firstly, MgAl-LDH with interlayer citrate was synthesized as a substrate. Then, $\mathrm{AgNO}_{3}$ solution was reacted with the $\mathrm{LDH}$ suspension. The $\mathrm{Ag} / \mathrm{Al}$ value, which is related to the $\mathrm{Ag} / \mathrm{LDH}$ ratio, was varied to find the optimum condition for size control. The developed SONPs were characterized in terms of crystallinity, chemical purity, particle size, and electronic structure, to suggest citrate LDH as an appropriate substrate for SONP synthesis with controlled size. In addition, the antibacterial activity of the homogeneously developed SONP compared with heterogeneous bulk silver oxide was evaluated by disk diffusion and colony forming inhibition assay.

\section{Materials and Methods}

\subsection{Materials}

Magnesium nitrate hexahydrate $\left(\mathrm{Mg}\left(\mathrm{NO}_{3}\right)_{2} \cdot 6 \mathrm{H}_{2} \mathrm{O}\right)$, aluminum nitrate nonahydrate $\left(\mathrm{Al}\left(\mathrm{NO}_{3}\right)_{3} \cdot 9 \mathrm{H}_{2} \mathrm{O}\right)$, sodium citrate tribasic dihydrate $\left(\mathrm{C}_{6} \mathrm{H}_{5} \mathrm{Na}_{3} \mathrm{O}_{7} \cdot 7 \mathrm{H}_{2} \mathrm{O}\right)$ and silver nitrate $\left(\mathrm{AgNO}_{3}\right)$ were obtained from Sigma-Aldrich Co. LLC. (St. Louis, MO, USA). Sodium hydroxide $(\mathrm{NaOH})$ was acquired from Daejung Chemicals and Metals Co. LTD. (Siheung, Gyeonggi-do, Korea). Luria-Bertani (LB) agar and LB broth were purchased from Becton, Dickinson and Company (BD, Sparks, MD, USA). All reagents were utilized without further purification.

\subsection{Preparation of Pristine $\mathrm{MgAl}$-Citrate $\mathrm{LDH}$}

Pristine $\mathrm{LDH}$ was prepared by the conventional co-precipitation method with citrate anion. Firstly, we mixed a solution of $\mathrm{Mg}\left(\mathrm{NO}_{3}\right)_{2} \cdot 6 \mathrm{H}_{2} \mathrm{O}(0.16 \mathrm{M})$ and $\mathrm{Al}\left(\mathrm{NO}_{3}\right)_{3} \cdot 9 \mathrm{H}_{2} \mathrm{O}$ $(0.079 \mathrm{M})$ and added $\mathrm{C}_{6} \mathrm{H}_{5} \mathrm{Na}_{3} \mathrm{O}_{7} \cdot 2 \mathrm{H}_{2} \mathrm{O}$ solution $(0.47 \mathrm{M})$. Next, the mixed solution was titrated with $1.2 \mathrm{M} \mathrm{NaOH}$ solution under a nitrogen atmosphere until $\mathrm{pH} 9.5$ was achieved. The suspension was stirred vigorously for $24 \mathrm{~h}$ at room temperature. After the reaction, the precipitate (MgAl-citrate $\mathrm{LDH}$ ) was obtained by centrifugation, washing and lyophilization.

\subsection{Preparation of Silver Oxide Nanoparticle Decorated LDH (SONP@LDH)}

To immobilize SONPs on an LDH surface, an $\mathrm{AgNO}_{3}$ solution was reacted with $\mathrm{LDH}$. For the reaction with different $\mathrm{Ag} / \mathrm{Al}$ molar ratios of $1,1 / 3$, and $1 / 10, \mathrm{AgNO}_{3}$ solution of the corresponding concentration 0.042, 0.014 and $0.0042 \mathrm{M}$ was prepared. MgAl-citrate $\mathrm{LDH}$ powder $(1 \mathrm{~g})$ was thoroughly dispersed in $100 \mathrm{~mL}$ of each $\mathrm{AgNO}_{3}$ solution. Then the reaction was conducted under vigorous stirring at room temperature. After $24 \mathrm{~h}$ of the reaction, the precipitate was collected by centrifugation, washing and lyophilization. The SONP decorated LDH was represented as SONP@LDH- $n$, where $n$ stands for the Ag/Al molar ratio in the reaction.

\subsection{Characterization}

In order to identify the structure of pristine MgAl-citrate LDH and SONP@LDHs, Xray diffraction (XRD, Ultima IV, Rigaku, Tokyo, Japan) with a $\mathrm{Cu} \mathrm{K} \alpha$ radiation $(\lambda=1.5406 \AA$ ) was utilized. Powder XRD patterns were measured in the $2 \theta$ range from $5^{\circ}$ to $80^{\circ}$ with 
a scanning rate of $0.05^{\circ} / \mathrm{s}$. Lattice parameters were determined using UnitCell software (Unitcell, Tim Holland and Simon Redfern, 2006, Cambridge University, Cambridge, UK) based on the acquired diffractograms. The chemical state of the silver was confirmed by X-ray photoelectron spectroscopy (XPS, K alpha+, Thermo VG, Waltham, MA, USA). The surface morphology of pristine MgAl-citrate LDH and SONP@LDH hybrids were observed using field emission-scanning electron microscopy (FE-SEM, Auriga, ZEISS, Oberkochen, Germany). The powder sample was dispersed in deionized water and drop-casted on a silicon wafer to prepare specimens for examination by scanning electron micrograph (SEM). Measurement was carried out at $15 \mathrm{kV}$ acceleration voltage after Pt sputtering specimen for $60 \mathrm{~s}$. In order to clearly identify the SONPs on SONP@LDHs, field emission transmission electron microscopy (FE-TEM) and selected area electron diffraction (SAED) pattern (Titan G2 ChemiSTEM Cs Probe, FEI, Hillsboro, OR, USA) were acquired. In conducting TEM, all samples were dispersed in deionized water with $10 \mathrm{~min}$ sonication and drop-casted on a $\mathrm{Cu}$ grid (200-square mesh gird with carbon film, Ted Pella, CA, USA). The TEM micrographs were acquired using a $200 \mathrm{kV}$ acceleration voltage. To obtain the average particle size of SONPs, 50 particles were randomly selected from TEM images micrographs. The electronic structure of SONP@LDH hybrids was analyzed by UV-vis diffuse reflectance spectroscopy (EVOLUTION 220, ThermoFisher Scientific, Waltham, MA, USA) in the wavelength range from 200 to $1000 \mathrm{~nm}$.

\subsection{Antibacterial Activity Test}

\subsubsection{Disk Diffusion Assay}

The antibacterial activity of samples was first determined by a disk diffusion assay against a Gram-negative bacterium, Escherichia coli (E. coli) by following a previous report [39]. The biological resources used in this research were distributed from Korean Collection for Type Cultures (KCTC, Jeongeup, Korea). The E. coli was cultured in an LB agar plate in an incubator at $37^{\circ} \mathrm{C}$ for overnight. Three colonies were inoculated in $5 \mathrm{~mL}$ of LB broth and cultivated in an incubator at $37^{\circ} \mathrm{C}$ for $24 \mathrm{~h}$. Commercially available bulk $\mathrm{Ag}_{2} \mathrm{O}$ with a heterogeneous particle size distribution (Silver (I) oxide, Sigma-Aldrich Co. LLC., St. Louis, MO, USA) was utilized as a reference sample.

Suspensions $(10 \mathrm{~mL})$ containing either bulk $\mathrm{Ag}_{2} \mathrm{O}$ or SONP@LDH $\left(\mathrm{Ag}_{2} \mathrm{O}\right.$ concentration $=5 \mathrm{mg} / \mathrm{mL}$ ) were sonicated for $30 \mathrm{~min}$ and $100 \mu \mathrm{L}$ of each suspension was applied on a punched paper filter (6 mm, ADVANTEC, Toyo Roshi Kaisha Ltd., Tokyo, Japan). The sample-loaded paper filter was dried on a hotplate at $80^{\circ} \mathrm{C}$ and stored in UV condition. Then, $20 \mathrm{~mL}$ of LB agar was poured into a petri dish and solidified at room temperature. E. coli bacterial suspension (LB broth medium, $10 \mu \mathrm{L}$ of $1.7 \times 10^{5}$ colony-forming units per $\mathrm{mL}$ ) was uniformly spread on the surface of the LB agar plate. The LB agar plates were incubated at $37^{\circ} \mathrm{C}$ for $24 \mathrm{~h}$. The antibacterial activities were investigated by the diameter of the zone of inhibition around each paper disk. Each experiment was performed in triplicates and the standard deviations are presented as the final values.

\subsubsection{Colony Forming Inhibition Test}

In order to quantify the antibacterial property of SONP@LDHs hybrids [40], colonyforming inhibition assay was carried out. Similar to Section 2.5.1, E. coli was selected and cultured. The bulk $\mathrm{Ag}_{2} \mathrm{O}$ and SONP@LDHs $\left(\mathrm{Ag}_{2} \mathrm{O}\right.$ content was set the same at $\left.10 \mathrm{mg}\right)$ were added in $10 \mathrm{~mL}$ of $E$. coli bacterial suspension $\left(1.7 \times 10^{5}\right.$ colony-forming units per $\left.\mathrm{mL}\right)$. Each mixed suspension was incubated in an incubator at $37^{\circ} \mathrm{C}$ for $24 \mathrm{~h}$. Negative control samples were prepared without Ag moiety or with pristine MgAl-citrate LDH.

To estimate the number of bacterial cells in suspension, an optical density at $600 \mathrm{~nm}$ of the bacterial suspension $(200 \mu \mathrm{L})$ was measured using a microplate reader (VARIOSKAN LUX, ThermoFisher SCIENTIFIC, MA, USA) [41]. In our work, 100- $\mu \mathrm{L}$ aliquots of the bacterial suspension were diluted 100 times and $20 \mu \mathrm{L}$ was plated on an LB agar plate and incubated at $37^{\circ} \mathrm{C}$ for $24 \mathrm{~h}$. The colonies were counted on the next day. The experiments were performed in triplicates. 


\section{Results}

\subsection{Crystal Structure Analysis}

The crystal structures of the pristine MgAl-citrate LDH and SONP@LDHs were confirmed using XRD patterns. The pristine LDH in Figure 1a exhibited well-developed (001) peaks in low angle $\left(2 \theta<25^{\circ}\right)$ region and lattice peaks at high angle region $\left(2 \theta>25^{\circ}\right)$, which are in agreement with a hydrotalcite phase reported in the Joint Committee on Powder Diffraction Standards (JCPDS) card No.14-0191, indicating an LDH structure [42]. According to the corresponding (003), (006), and (009) peaks at $6.79^{\circ}, 14.0^{\circ}$, and $21.4^{\circ}$, the d-spacing of the pristine MgAl-citrate LDH calculated by Bragg's equation $(n \cdot \lambda=2 \mathrm{~d} \cdot \sin \theta, n$ : an integer (usually 1), d: d-spacing, $\theta$ : Bragg angle) [43] was $13.0 \AA$, which is slightly higher than a previously reported value of $12 \AA$ [44]. This discrepancy was not serious as the $\mathrm{d}$-spacing can be varied by degree of interlayer hydration. According to the molecular dynamics simulation report, the d-spacing of citrate-intercalated LDH could range between 9.39 and $15.6 \AA$, with a hydration number $(n)$ between 3 and $12\left(\mathrm{Mg}_{3} \mathrm{Al}(\mathrm{OH})_{8}\right.$ (citrate) $\left.0.33 \cdot \mathrm{nH}_{2} \mathrm{O}\right)$ [45]. As the literature suggested that hydration number and d-spacing had an almost linear relationship, we could estimate that the current MgAl-citrate LDH had hydration number 8-9. The degree of hydration is not discussed in detail here, as the MgAl-citrate LDH was subjected to aqueous reaction. Under water suspension, the hydration number does not have important meaning due to the dynamic changes in hydration state. Due to the sustained release property of LDH toward intercalated moiety $[38,44]$, the citrate anion would be provided in a sustained manner during SONP formation. The acidity of $\mathrm{AgNO}_{3}$ partially dissolved $\mathrm{LDH}$ at the periphery, and the produced $\mathrm{OH}^{-}$moieties, react with $\mathrm{Ag}^{+}$ (Equation (1) and (2)) [10]. The released citrate also reacted with $\mathrm{Ag}^{+}$as a capping agent, also participating $\mathrm{Ag}_{2} \mathrm{O}$ crystal growth (Equation (3) and (4)) [36,46]. The combination of several chemical reactions is thought to inhibit the crystal growth of SONP.

$$
\begin{gathered}
\mathrm{Ag}^{+}(\mathrm{aq})+\mathrm{Mg}_{2} \mathrm{Al}(\mathrm{OH})_{6}{ }^{+}(\mathrm{s}) \rightleftharpoons(1-\mathrm{x}) \mathrm{Ag}^{+}(\mathrm{aq})+\mathrm{xAg}(\mathrm{OH})(\mathrm{s})+\mathrm{Mg}_{2} \mathrm{Al}(\mathrm{OH})_{6-\mathrm{x}}{ }^{(1+\mathrm{x})+}(\mathrm{s}) \\
2 \mathrm{Ag}(\mathrm{OH})(\mathrm{s}) \rightleftharpoons \mathrm{Ag}_{2} \mathrm{O}(\mathrm{s})+\mathrm{H}_{2} \mathrm{O}(\mathrm{l}) \\
3 \mathrm{Ag}^{+}(\mathrm{aq})+(\mathrm{citrate})^{3-}(\mathrm{aq}) \rightleftharpoons \mathrm{Ag}_{3}(\text { citrate })(\mathrm{aq}) \\
2 \mathrm{Ag}_{3}(\text { citrate })(\mathrm{aq})+6 \mathrm{OH}^{-}(\mathrm{aq}) \rightarrow 3 \mathrm{Ag}_{2} \mathrm{O}(\mathrm{s})+(\text { citrate })^{3-}(\mathrm{aq})+3 \mathrm{H}_{2} \mathrm{O}(\mathrm{l})
\end{gathered}
$$

(a)

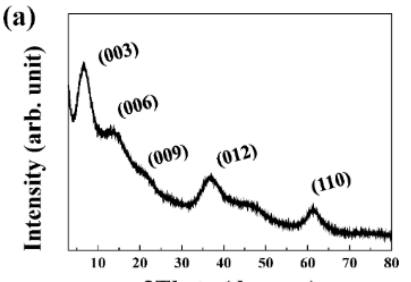

(c)

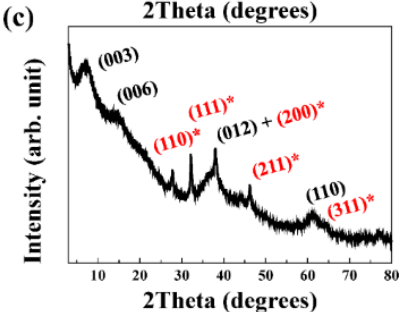

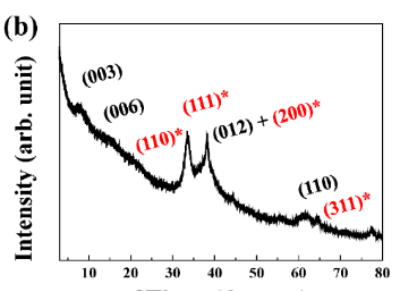

(d)

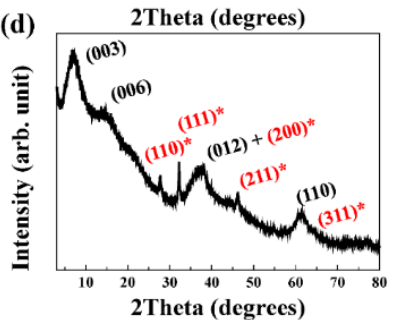

Figure 1. X-ray diffraction (XRD) patterns of (a) pristine MgAl-citrate layered double hydroxide (LDH), (b) Silver oxide nanoparticle (SONP)@LDH-1, (c) SONP@LDH-1/3 and (d) SONP@LDH-1/10 (black (hkl) notation: LDH, red(*) (hkl) notation: silver oxide).

As expected above, the XRD patterns of SONP@LDHs in Figure 1b-d show characteristic patterns for $\mathrm{Ag}_{2} \mathrm{O}$; peaks at $27.7^{\circ}, 32.2^{\circ}, 38.0^{\circ}, 46.2^{\circ}$, and $64.5^{\circ}$ attributed to (110), (111), (200), (211), and (311) of $\mathrm{Ag}_{2} \mathrm{O}$ (JCPDS card No.76-1393) [47,48]. These results 
suggested that a cubic crystal system with lattice parameter $a=4.81 \AA$ was obtained for the synthesized SONP, although this is slightly larger than $4.76 \AA$ for standard silver oxide $\left(\mathrm{Ag}_{2} \mathrm{O}\right)$, [49]. The slightly larger lattice parameter can be explained by the small particle size of oxide nanoparticles, which tended to show the expanded lattice compared with its bulk counterpart [50]. The presence of citrate as a capping agent rendered a negatively charged SONP, making it easy to electrostatically attach on a positive surface of LDH [51].

Although we could observe characteristic XRD peaks for LDH at the same position in all the SONP@LDHs, peak intensity and width were different from each other. The crystallinity of each sample was calculated by the Scherrer's equation $(t=0.9 \lambda / B \cos \theta, t$ : crystallite size $(\AA), \lambda$ : X-ray wavelength $(\AA), B$; full-width at half-maximum of a peak, $\theta$ : Bragg angle) [52]. This has yielded a corresponding crystallite size of 2.63, 1.49, 2.13, and $2.50 \mathrm{~nm}$ along c-axis of LDH lattice for pristine LDH, SONP@LDH-1, SONP@LDH-1/3, and SONP@LDH-1/10. The results suggested that the larger quantity of $\mathrm{Ag}^{+}$facilitated more dissolution of $\mathrm{LDH}$, giving rise to a partial collapse of the LDH layer. Enhanced release of $\mathrm{OH}^{-}$and citrate in SONP@LDH-1 influenced the formation of SONP, possibly resulting in unregulated crystal growth. As the XRD showed different crystallographic characters of $\mathrm{LDH}$ concerning for $\mathrm{Ag} / \mathrm{Al}$ ratio, it is expected that the size and distribution of SONPs would be influenced accordingly, which will be discussed in the successive section.

\subsection{Quantification of SONP@LDHs and Microscopic Analysis}

Chemical compositions of samples were quantitatively evaluated with XPS and the results are summarized in Table 1 . These results show that the amount of SONPs in the hybrid increased from $6.1 \%$ to $12 \%$, and $23 \%$ for the corresponding $\mathrm{Ag} / \mathrm{Al}$ ratio of $1 / 10$, $1 / 3$, and 1 . The nominal $\mathrm{Ag}_{2} \mathrm{O}$ contents were estimated assuming all silver nitrate reacted to form $\mathrm{Ag}_{2} \mathrm{O}$. The empirical $\mathrm{Ag}_{2} \mathrm{O}$ contents were determined by the quantification result of XPS measurement. However, these quantities of SONPs in the hybrid were less than the corresponding nominal value of $5.1 \%, 16 \%$ and $35 \%$. The ratio between empirical to nominal $\mathrm{Ag}_{2} \mathrm{O}$ content was $0.66,0.75$, and 1.2, respectively, for $\mathrm{Ag} / \mathrm{Al}$ ratio 1/1, 1/3, and $1 / 10$. The tendency was due to the low availability of $\mathrm{Ag}^{+}$when the $\mathrm{Ag} / \mathrm{Al}$ ratio was high. Through the mismatch between nominal and empirical content, we could guess that the difference in $\mathrm{Ag} / \mathrm{Al}$ ratio influenced how much $\mathrm{Ag}^{+}$participated in the SONP formation. The difference would affect both surface property and particle morphology of SONPs. Therefore, we observed the morphology aspect in detail, utilizing electron microscopic techniques.

Table 1. Chemical formulae of pristine MgAl-citrate LDH, SONP@LDH-1, SONP@LDH-1/3 and SONP@LDH-1/10. Nominal composition was calculated by hypothesizing all $\mathrm{Ag}^{+}$participated in SONP production. Empirical composition was the quantitative analysis results from XPS.

\begin{tabular}{|c|c|c|c|c|}
\hline & \multicolumn{2}{|l|}{ Nominal Composition } & \multicolumn{2}{|l|}{ Empirical Composition } \\
\hline & Chemical Formulae & $\begin{array}{c}\operatorname{Ag}_{2} \mathrm{O} \\
\text { Contents } \\
(\%)\end{array}$ & Chemical Formulae & $\begin{array}{c}\mathrm{Ag}_{2} \mathrm{O} \\
\text { Contents } \\
(\%)\end{array}$ \\
\hline MgAl-citrate LDH & $\mathrm{Mg}_{1.6} \mathrm{Al}(\text { citrate })_{0.33}(\mathrm{OH})_{5.2}$ & - & $\mathrm{Mg}_{1.6} \mathrm{Al}(\text { citrate })_{0.33}(\mathrm{OH})_{5.2}$ & - \\
\hline SONP@LDH-1 & $\mathrm{Mg}_{1.6} \mathrm{Al}(\text { citrate })_{0.33}(\mathrm{OH})_{5.2}\left(\mathrm{Ag}_{2} \mathrm{O}\right)_{0.50}$ & 35 & $\mathrm{Mg}_{1.5} \mathrm{Al}(\text { citrate })_{0.33}(\mathrm{OH})_{5.0}\left(\mathrm{Ag}_{2} \mathrm{O}\right)_{0.28}$ & 23 \\
\hline SONP@LDH-1/3 & $\mathrm{Mg}_{1.6} \mathrm{Al}(\text { citrate })_{0.33}(\mathrm{OH})_{5.2}\left(\mathrm{Ag}_{2} \mathrm{O}\right)_{0.17}$ & 16 & $\mathrm{Mg}_{1.5} \mathrm{Al}(\text { citrate })_{0.33}(\mathrm{OH})_{5.0}\left(\mathrm{Ag}_{2} \mathrm{O}\right)_{0.12}$ & 12 \\
\hline SONP@LDH-1/10 & $\mathrm{Mg}_{1.6} \mathrm{Al}(\text { citrate })_{0.33}(\mathrm{OH})_{5.2}\left(\mathrm{Ag}_{2} \mathrm{O}\right)_{0.050}$ & 5.1 & $\mathrm{Mg}_{1.4} \mathrm{Al}(\text { citrate })_{0.33}(\mathrm{OH})_{4.8}\left(\mathrm{Ag}_{2} \mathrm{O}\right)_{0.057}$ & 6.1 \\
\hline
\end{tabular}

As shown in the scanning electron micrographs in Figure 2a, pristine LDH consisted of agglomerates of irregularly shaped small particles with a relatively smooth surface. On the other hand, as shown in Figure $2 b-d$, small particles assumed to be SONPs began to appear at the surface of large particles. The SONP@LDH-1 apparently exhibited the development of small particles on a large lump in Figure $2 \mathrm{~b}$. The number of particles decreased according to the diminishing $\mathrm{Ag} / \mathrm{Al}$ ratio. In addition to the number of $\mathrm{Ag}_{2} \mathrm{O}$ particles, there is also a clear difference in morphology. In the scanning electron micrographs of SONP@LDH-1 in 
Figure $2 b$, particle size and shape of the SONPs were irregular with most of them forming aggregates of heterogeneous particles with sizes ranging from tens of nanometers to a few hundred nanometers (arrows in Figure 2). In Figure 2c, the number of irregular SONP particles decreased, but an aggregation of those particles was also observed. Particle size, shape, and distribution of small particles (SONPs) became homogeneous with decreasing $\mathrm{Ag} / \mathrm{Al}$ ratio. The scanning electron micrographs in Figure 2d, exhibited that SONP@LDH$1 / 10$ contained SONPs with homogeneous size and spherical shape.

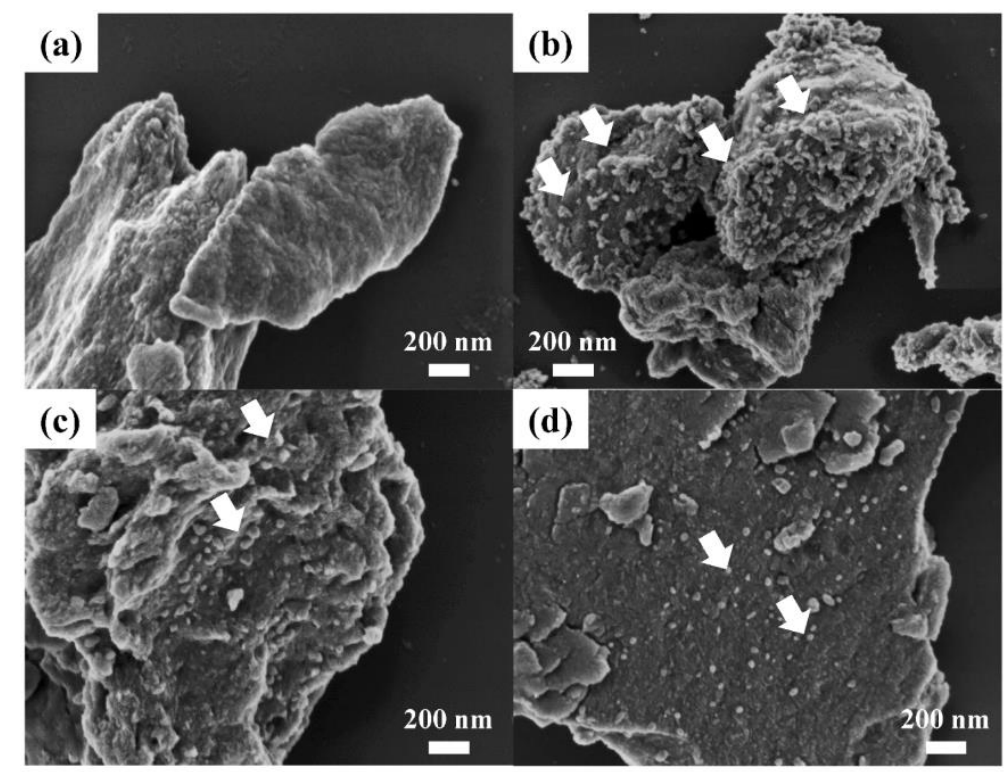

Figure 2. Field emission-scanning electron micrographs of (a) pristine $\mathrm{MgAl}$-citrate LDH, (b) SONP@LDH-1, (c) SONP@LDH-1/3 and (d) SONP@LDH-1/10.

To study in more detail the particle size of SONPs and their distribution, we carried out transmission electron microscopy. In Figure 3a, pristine LDH showed particles of tens of nanometers. We observed lattice fringe of which distance was $0.24 \mathrm{~nm}$ (Figure $3 \mathrm{~b}$ ). It indicated that the sample contained a crystalline array of certain planes with inter-plane distance $0.24 \mathrm{~nm}$. From the XRD patterns of MgAl-citrate LDH (Figure 1a), we apparently observed (012) with d-spacing of $0.24 \mathrm{~nm}$ by Bragg's equation. Therefore, we assigned that the observed lattice fringe was attributed to the arrangement of (012) planes in LDH. Furthermore, the selected area electron diffraction (SAED) pattern was obtained to show the existence of LDH. The SAED is a powerful tool to show the local crystal structure by diffracting the electron beam at a certain region. We observed clear ring patterns at 8.13 and $12.11 / \mathrm{nm}$ reciprocal lattice position (Figure $3 \mathrm{c}$ ). The values in reciprocal space (SAED pattern) corresponded to the inter-plane distance of 0.123 and $0.0826 \mathrm{~nm}$, respectively. These values well matched with the d-spacing values of (012) and (110) of LDH as observed in the XRD patterns (Figure 1a). Similar to the lattice fringe results above, the electron diffraction patterns in Figure $3 \mathrm{c}$ indicated the existence of crystalline LDH in the selected area. In Figure 3d, we observed particles with $39.45 \pm 24.47 \mathrm{~nm}$ on a large platelet. In the higher magnification micrograph $(100,000 \times)$ shown in Figure 3e, lattice fringes with distance 0.23 and $0.27 \mathrm{~nm}$, respectively, were clearly observed. The inter-plane distance values matched with the d-spacing values of (200) and (111) in SONP. As the crystalline peaks, (200) and (111), were observed in XRD (Figure 1b), we could assign that the two lattice fringes were attributed to the arrays of (200) and (111) in SONP. The result confirmed that the particles with dotted circles in transmission electron micrographs were SONPs. The particle size and the standard deviation of SONPs became small with decreasing Ag/Al ratio: $20.75 \pm 11.76 \mathrm{~nm}$ and $9.79 \pm 3.23 \mathrm{~nm}$ for SONP@LDH-1/3 and SONP@LDH-1/10, respectively (Figure $3 g, j$ ). It was worth noting that the SONP@LDH-1/10 hybrid showed well-controlled $\mathrm{Ag}_{2} \mathrm{O}$ nanoparticles with narrow-sized distribution and homogeneous 
distribution. As described previously, we detected lattice fringes corresponding to SONPs in the TEM micrograph of SONP@LDH-1 (Figure 3e). The electron diffraction patterns of SONP@LDH samples (Figure 3f,I,l) at the particle region (dotted circles in Figure 3e,h,k) showed signals at 7.61, 8.37, 10.1, and $13.91 / \mathrm{nm}$. The values in reciprocal space corresponded to $0.131,0.119,0.990$, and $0.719 \mathrm{~nm}$, respectively. These were the same with the $\mathrm{d}$-spacing values of (111), (200), (211), and (311) in $\mathrm{Ag}_{2} \mathrm{O}$. Therefore, we could conclude that the particles in transmission electron micrographs were SONP particles. To evaluate the distribution of SONPs, we gained energy dispersive spectroscopy mapping based on transmission electron micrograph (Supplementary Materials Figures S1-S4). As described above, SONP@LDH-1 and SONP@LDH-1/3 had a huge agglomerate of SONPs. On the other hand, SONP@LDH-1/10 showed a homogeneous distribution of Ag throughout the sample. Through these results, we could suggest that the $\mathrm{Ag} / \mathrm{Al}$ ratio influenced the particle size of SONPs and controlled the distribution of particles.

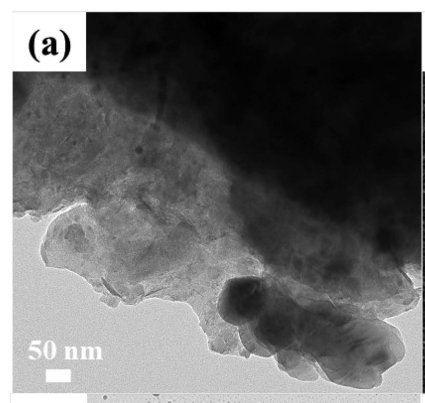

(d)
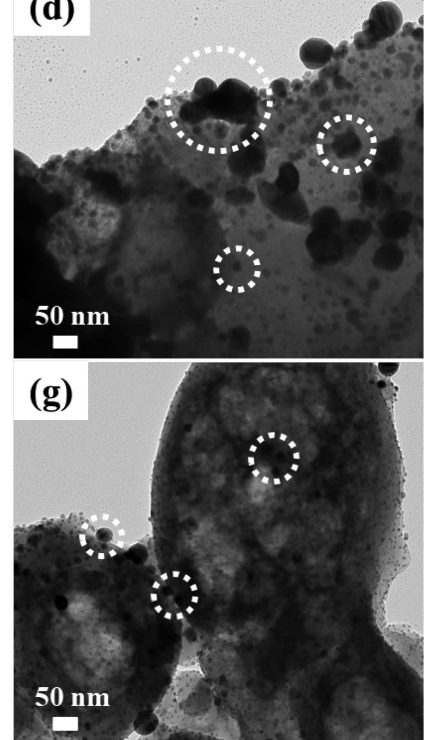

(j)

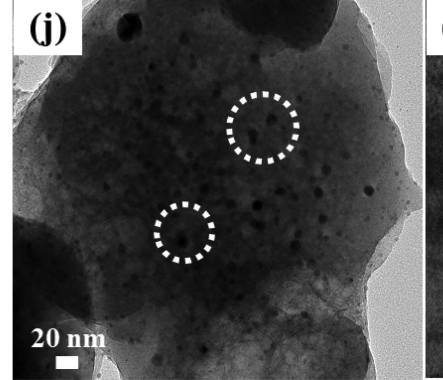

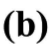

(b)

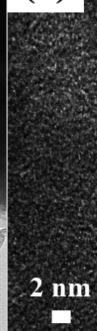

(e)

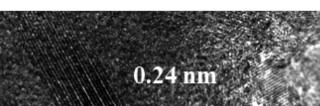

hlive
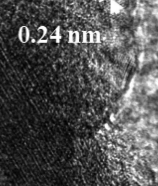

(c)

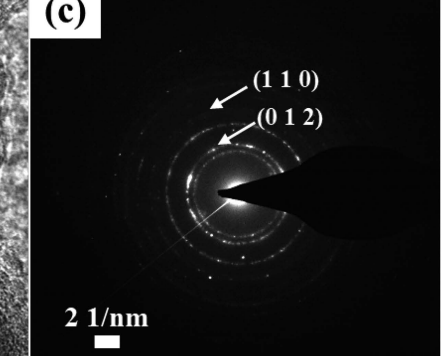

(f)
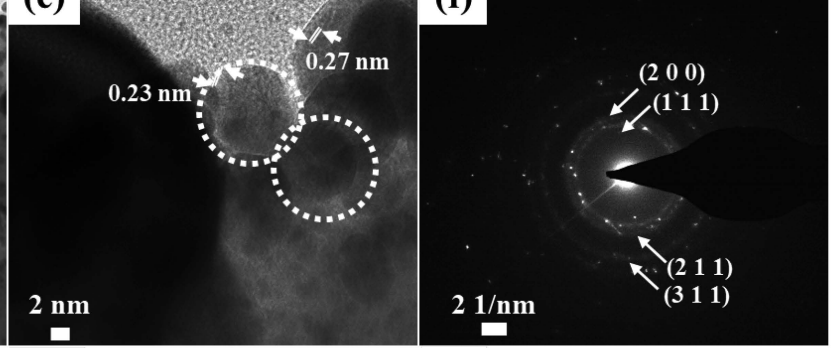

(h)

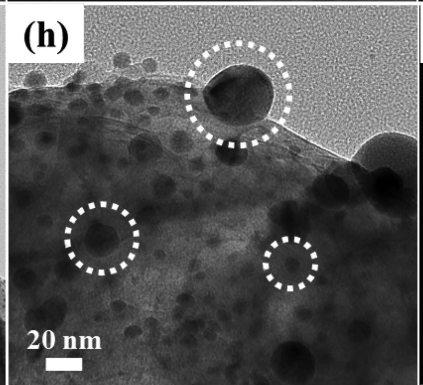

(i)

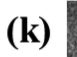

(k)
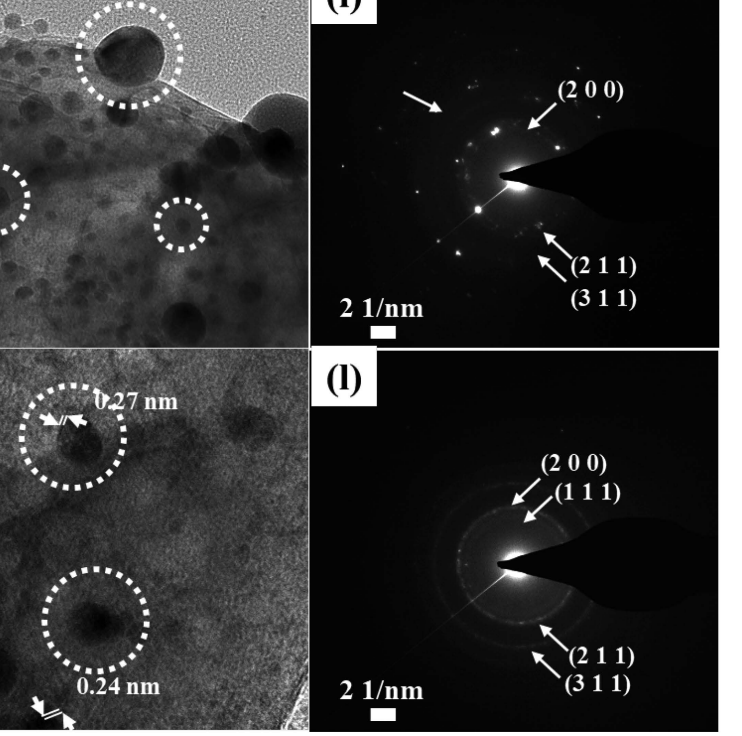

(l)

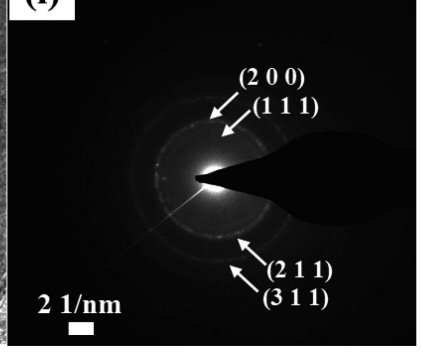

Figure 3. Transmission electron micrographs, higher magnification transmission electron micrograph $(100,000 \times)$ with lattice fringes and selected area electron diffraction (SAED) patterns of pristine (a-c) MgAl-citrate LDH, (d-f) SONP@LDH-1, (g-i) SONP@LDH-1/3, and (j-1) SONP@LDH-1/10. Dotted circles stand for the SONPs. 


\subsection{Chemical Environments of Ag in SONP@LDHs}

The crystal structure of SONPs did not show a significant difference depending on $\mathrm{Ag} / \mathrm{Al}$ ration in the XRD patterns and the SAED patterns. However, SEM and TEM observation presented that different particle morphology could be obtained according to $\mathrm{Ag} / \mathrm{Al}$ ratio. The discrepancy was addressed by investigating the chemical environment of $\mathrm{Ag}$ utilizing XPS. As shown in Figure 4, the peak positions of all the samples were similar. The spectra for $\mathrm{Ag} 3 \mathrm{~d}$ electrons exhibited two peaks at $374.03\left(3 \mathrm{~d}_{3 / 2}\right)$ and $367.96 \mathrm{eV}\left(3 \mathrm{~d}_{5 / 2}\right)$, which was well-matched with the binding energies of pure $\mathrm{Ag}_{2} \mathrm{O}$ at $373.90\left(3 \mathrm{~d}_{3 / 2}\right)[53]$ and $367.7 \mathrm{eV}\left(3 \mathrm{~d}_{5 / 2}\right)$ [54]. As the binding energy of an electron is strongly influenced by the chemical environment such as the type of adjacent atoms, and coordination number, the broad shape of the XPS peak suggested that the electrons are located in a complex chemical matrix. The shape of peaks differed depending on the Ag/Al ratio. The SONP@LDH-1 presented broad peaks, and SONP@LDH-1/3 exhibited humped peaks. The results implied that the SONP@LDH-1 and SONP@LDH-1/3 would have a complex chemical environment on $\mathrm{Ag}$ such as $\mathrm{Ag}(0)$ or $\mathrm{AgO}$. Different formation processes of SONPs depending on the $\mathrm{Ag} / \mathrm{Al}$ ratio might influence the chemical environment. At a low $\mathrm{Ag} / \mathrm{Al}$ ratio, a large amount of $\mathrm{LDH}$ compared with $\mathrm{Ag}^{+}$facilitated crystal growth of $\mathrm{Ag}_{2} \mathrm{O}$ in a controlled manner. Meanwhile, increasing the $\mathrm{Ag} / \mathrm{Al}$ ratio would negatively affect the controlled crystal growth of $\mathrm{Ag}_{2} \mathrm{O}$, resulting in disorganized phase and particle aggregation. The results suggested that the SONPs decoration on LDH surface with high purity and homogeneity depended on the ratio between $\mathrm{LDH}$ and $\mathrm{Ag}^{+}$source.

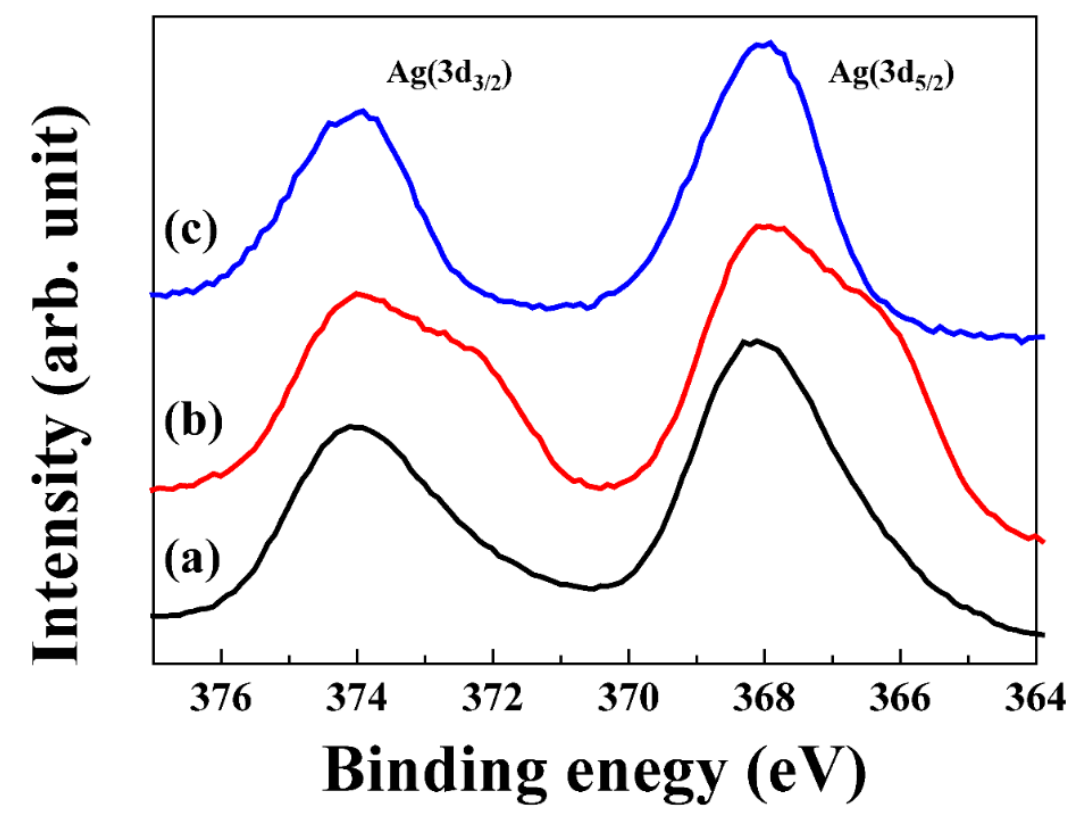

Figure 4. X-ray photoelectron spectroscopy (XPS) profiles for Ag 3d electrons of (a) SONP@LDH-1, (b) SONP@LDH-1/3 and (c) SONP@LDH-1/10.

\subsection{Electronic Structure of SONP@LDHs}

After pristine $\mathrm{LDH}$ reacted with $\mathrm{AgNO}_{3}$ solution, the color of the suspension changed gradually from white to pale grey, indicating the generation of $\mathrm{Ag}_{2} \mathrm{O}$. To examine the electronic configuration of both LDH and SONP part in the hybrid, solid-state UV-vis spectroscopy was conducted. While pristine LDH showed two intense absorption peaks at 223 and $300 \mathrm{~nm}$ (Figure 5a), SONP@LDHs showed an intense peak at around $223 \mathrm{~nm}$ and broad absorption in the visible light region (Figure $5 \mathrm{~b}-\mathrm{d}$ ). The broad absorption $300-600 \mathrm{~nm}$ has frequently been reported in the presence of $\mathrm{Ag}_{2} \mathrm{O}$ [55-57]. We expect to observe similar broad absorption (see Figure $5 b-d$ ) in the spectrum of SONP. Although all the SONP@LDHs exhibited similar light absorption patterns, we observed a difference in peak position depending on the $\mathrm{Ag} / \mathrm{Al}$ ratio. To quantitatively analyze the difference, 
we converted the graphs to Kubelka-Munk reflectance spectra based on the Tauc formula $(\alpha h v)^{1 / \gamma}=\mathrm{B}\left(h v-E_{\mathrm{g}}\right)$, where $\alpha$ is the energy-dependent absorption coefficient, $h$ is the Planck constant, $v$ is the photon's frequency, $\mathrm{E}_{\mathrm{g}}$ is the band-gap energy and B is a constant. The $\gamma$ factor is the nature of the electron and is equal to $1 / 2$ or 2 for direct and indirect transition band-gap, respectively [58]. The left and right panels of the inset in Figure $5 \mathrm{~b}-\mathrm{d}$ indicate the band-gap energy originated from LDH and SONP, respectively. The calculated band-gap values for SONPs in SONP@LDHs were correspondingly 2.02, 2.19, and $2.34 \mathrm{eV}$ for Ag/ Al ratio $1,1 / 3$, and $1 / 10$, all of which are within the previously reported 1.3 to $2.35 \mathrm{eV}$ range for $\mathrm{Ag}_{2} \mathrm{O}$ [1-3]. The band-gap energy is affected by both particle size and phase purity of $\mathrm{Ag}_{2} \mathrm{O}$. It is generally known that the reduced size in nanoparticles increased band-gap energy [59-61]. Recent research on $\mathrm{Ag}_{2} \mathrm{O}$ reported that the existence of impurity or defect in $\mathrm{Ag}_{2} \mathrm{O}$ could decrease band-gap [62]. The smallest size (Figure 3j) and the highest purity (Figure $4 \mathrm{c}$ ) of SONP at the $\mathrm{Ag} / \mathrm{Al}$ ratio 1/10 rationalized the largest band-gap.
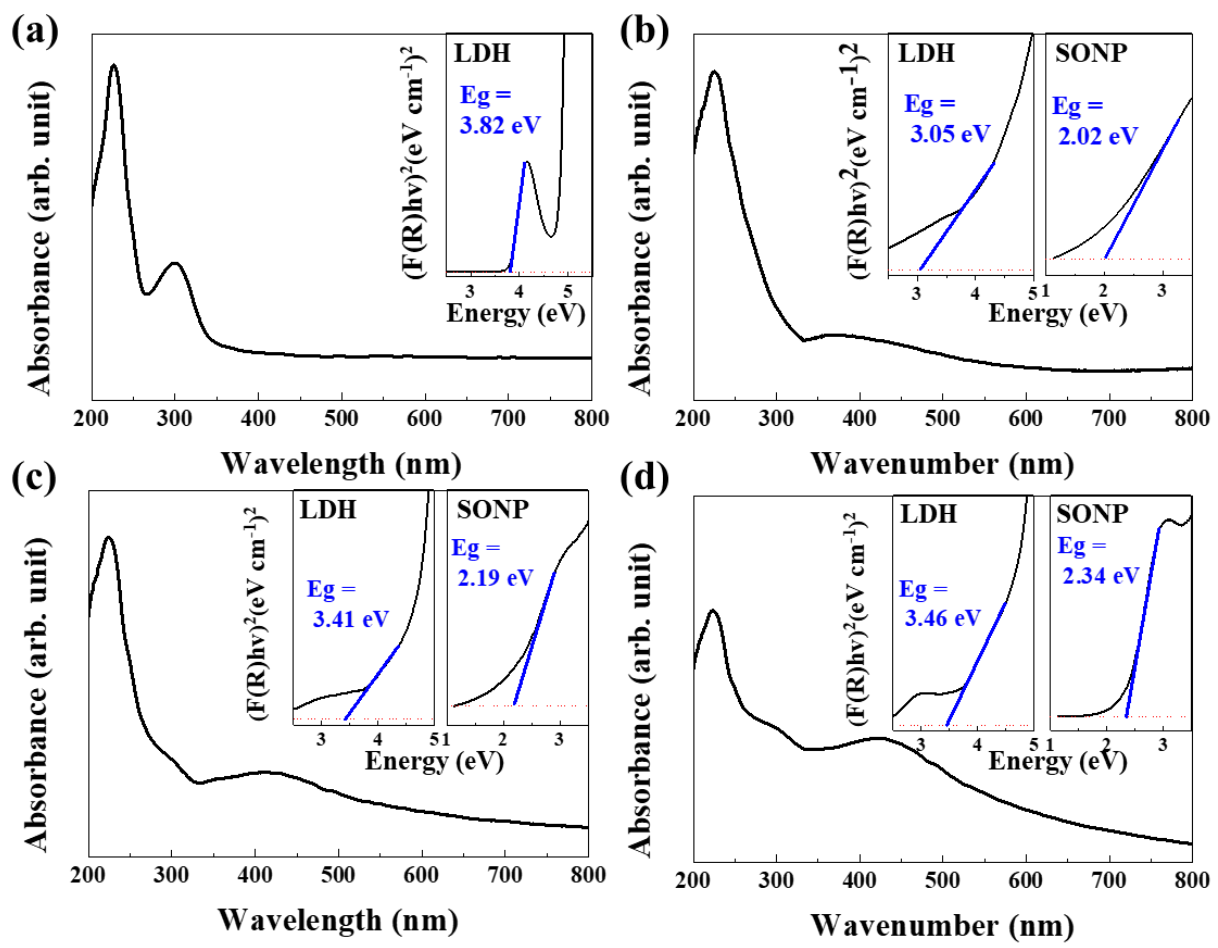

Figure 5. Diffuse reflectance UV-visible absorption spectra of (a) pristine MgAl-citrate LDH, (b) SONP@LDH-1, (c) SONP@LDH-1/3 and (d) SONP@LDH-1/10. Kubelka-Munk-transformed reflectance spectra and band-gaps were displayed as insets.

In addition to the band-gap change in SONP, we also observed that the band-gap energy of the LDH part was altered depending on the $\mathrm{Ag} / \mathrm{Al}$ ratio. The $\mathrm{M}(\mathrm{OH})_{6}$ octahedron in LDH showed ligand-to-metal charge transfer excitations in the 200 to $300 \mathrm{~nm}$ range [63], the energy-gap being influenced by the crystallinity. Reportedly, LDHs with low crystallinity demonstrated a smaller band-gap than those with high crystallinity $[64,65]$. Parida et al. [65] reported decreasing band-gap energy from 2.80 to $1.86 \mathrm{eV}$ depending on the crystallinity. In Figure 5a, the band-gap originated from LDH had $3.82 \mathrm{eV}$, while the corresponding hybrid samples correspondingly showed 3.05, 3.41, and $3.46 \mathrm{eV}$ for SONP@LDH-1, 1/3, and 1/10, respectively. The band-gap of the LDH part reflected the crystallinity of $\mathrm{LDH}$ at different $\mathrm{Ag} / \mathrm{Al}$ ratios.

\subsection{Antibacterial Effect of SONP@LDHs}

The advantage of homogeneous SONP particle size was clearly shown in the antibacterial test. For comparative study, commercially available bulk $\mathrm{Ag}_{2} \mathrm{O}$ with a heterogeneous particle size (Supplementary Materials Figure S5) was selected as reference material. First, 
a disk diffusion test was carried out to study the antibacterial activity of SONPs. Disks containing each sample were located on an agar plate where bacteria were inoculated. Upon incubation at an appropriate condition, the bacteria grew on the plate, except the periphery of antibacterial disks. The higher the antibacterial efficacy, the larger zone of inhibition around the disk is observed. As shown in Figure 6a and Supplementary Materials Figure S6, the SONPs prepared on LDH surface showed a larger zone of inhibition than bulk $\mathrm{Ag}_{2} \mathrm{O}$. We also observed that the SONP@LDH-1/10, which showed the smallest and the most homogeneous SONP particles among the three samples, exhibited the largest inhibition zone for E. coli. As previously described [17], smaller SONP particles facilitated the release of $\mathrm{Ag}^{+}$ions from the particle surface to the medium due to the large specific surface area. In this regard, SONP@LDH-1/10, which had the smallest SONP particles could effectively release $\mathrm{Ag}^{+}$ions and accordingly showed a higher antibacterial effect on the contacted bacterial cells. The antibacterial mechanism of released $\mathrm{Ag}^{+}$ions from SONPs has been proposed by several research groups. Due to the strong affinity of $\mathrm{Ag}^{+}$ ions for sulfur [66], the released $\mathrm{Ag}^{+}$can interrupt disulfide bond or bind to thiol group in enzyme, resulting in the inactivation [67]. During the reaction between $\mathrm{Ag}^{+}$and thiol or disulfide group, $\mathrm{HS}^{-}$and $\mathrm{S}^{2+}$ are produced and they finally generate electrons through redox reaction. Through a set of reactions as described below, bacterial cells like E. coli consequently produce $\mathrm{ROS}$ such as $\mathrm{O}_{2}{ }^{-}, \mathrm{OH}^{-}, \mathrm{OH}$ and $\mathrm{H}_{2} \mathrm{O}_{2}$ that damage cell membrane proteins to suppress proliferation [68]. For example, $\mathrm{Ag}^{+}$ions bound to succinate dehydrogenase or aconitase which contain iron-sulfur clusters, are known to promote the formation of hydroxyl radicals by the Fenton reaction [69]. Furthermore, the literature suggested that the thiol group occupied by $\mathrm{Ag}^{+}$ions loses detoxification ability against ROS, finally resulting in bacterial suppression.

$$
\begin{gathered}
\mathrm{O}_{2}+\mathrm{e} \rightarrow \mathrm{O}_{2}^{-} \\
2 \mathrm{O}_{2}^{-}+2 \mathrm{H}^{+} \rightarrow \mathrm{H}_{2} \mathrm{O}_{2}+\mathrm{O}_{2}^{-} \\
\mathrm{O}_{2}^{-}+\mathrm{H}_{2} \mathrm{O}_{2} \rightarrow \mathrm{OH}^{-}+\cdot \mathrm{OH}+\mathrm{O}_{2}^{-}
\end{gathered}
$$

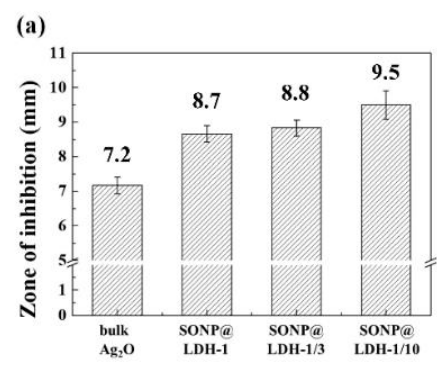

(b)

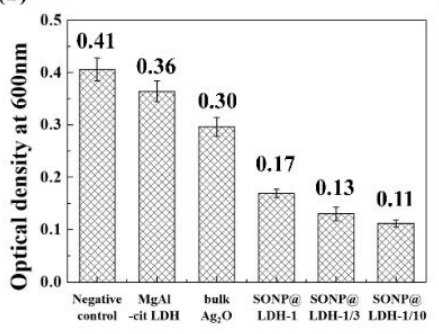

(c)

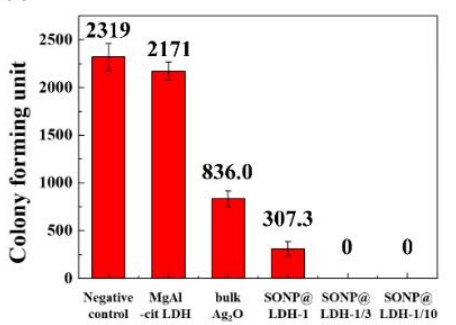

Figure 6. Antibacterial activity investigation by (a) zone of inhibition assay on LB agar plate, (b) optical density measurement at $600 \mathrm{~nm}$ after batch growth in liquid culture and (c) colony forming unit test on LB agar plate against Escherichia coli (E. coli.).

Another antibacterial action of $\mathrm{Ag}^{+}$is its interaction with nucleic acids [70]. Cellular internalized $\mathrm{Ag}^{+}$can intervene in the triple or double hydrogen bonds of DNA base-pairs, giving rise to DNA damages or inhibition of DNA replication [68].

The antibacterial effect of SONPs was also demonstrated by directly adding the sample suspension before E. coli incubation. After incubation, the degree of antibacterial suppression was evaluated by measuring the number of cells or by counting the number of colonies. The number of bacterial cells can be estimated by measuring the optical density (absorbance) of bacterial solution at wavelength $600 \mathrm{~nm}$. According to the previous literature [41], the optical density is directly proportional to the number of bacterial cells, where an optical density of 1.0 usually corresponds to approximately $1.0 \times 10^{8}$ cells $/ \mathrm{mL}$. In the cell number evaluation, the optical density at $600 \mathrm{~nm}$ was measured after overnight incubation at $37^{\circ} \mathrm{C}$. Figure $6 \mathrm{~b}$ exhibited that the E. coli without any treatment had fairly 
high optical density, which was directly proportional to the cell concentration. Both MgAlcitrate $\mathrm{LDH}$ and bulk $\mathrm{Ag}_{2} \mathrm{O}$ did not reduce the optical density of E. coli significantly. However, the three SONP@LDH prepared in this work showed a dramatic reduction in optical density. Among the three SONP@LDH, the one with the smallest SONP with the most homogeneous distribution (SONP@LDH-1/10) exhibited the lowest optical density. The antibacterial tendency was cross-confirmed by the colony-forming assays (Figure $6 \mathrm{c}$ and Supplementary Materials Figure S7). While bulk $\mathrm{Ag}_{2} \mathrm{O}$ showed an only $\sim 2.7$ times reduced number for the colony compared with negative control, SONP@LDH-1 exhibited a 7.6 times lowered number of colonies. Furthermore, samples with more homogeneous SONPs such as SONP@LDH-1/3 and SONP@LDH-1/10, had 100\% performance in colony inhibition. It should be noted here that $\mathrm{MgAl}$-citrate LDH did not significantly affect colony-forming of E. coli. The result clearly showed that the SONPs prepared in this work increased antibacterial effect, due to the homogeneity in particle.

\section{Conclusions}

SONPs were successfully developed on the surface of LDH, while the intercalated citrate served as a size controlling moiety. The presence of $\mathrm{Ag}^{+}$ions would partially cause the partial dissolution of the $\mathrm{LDH}$ lattice to release $\mathrm{OH}^{-}$ions to form $\mathrm{Ag}_{2} \mathrm{O}$. During the process, partially released citrate ions interacted with $\mathrm{Ag}^{+}$to suppress the crystal growth of SONPs. According to the microscopic measurement, the $\mathrm{Ag} / \mathrm{Al}$ ratio influenced the particle size and homogeneity of SONPs. In addition, XPS analysis revealed that the high $\mathrm{Ag} / \mathrm{Al}$ ratio tends to produce SONPs with a complex chemical environment. UV-vis spectroscopy confirmed that the SONPs prepared at a low $\mathrm{Ag} / \mathrm{Al}$ ratio was small in size and pure in composition. Moreover, SONP@LDHs with homogeneous particle size demonstrated significantly higher antibacterial activity against $E$. coli than bulk $\mathrm{Ag}_{2} \mathrm{O}$ with heterogeneous particle size. We suggest that the citrate-LDH could be utilized as a substrate to grow SONP, and that the $\mathrm{Ag} / \mathrm{Al}$ ratio, i.e., $\mathrm{Ag} / \mathrm{LDH}$ ratio, was a determining parameter to control particle size, distribution, and purity of SONPs. Furthermore, the antibacterial activity test clearly presented a close relationship with particle size and homogeneity.

Supplementary Materials: The following are available online at https: / www.mdpi.com/2079-4 991/11/2/455/s1, Figure S1: High-angle annular dark-field (HAADF) and TEM energy dispersive spectroscopic (EDS) mapping images of pristine MgAl-citrate LDH, Figure S2. High-angle annular dark-field (HAADF) and TEM energy dispersive spectroscopic (EDS) mapping images of SONP@LDH-1, Figure S3. High-angle annular dark-field (HAADF) and TEM energy dispersive spectroscopic (EDS) mapping images of SONP@LDH-1/3 and Figure S4. High-angle annular dark-field (HAADF) and TEM energy dispersive spectroscopic (EDS) mapping images of SONP@LDH-1/10. Figure S5. Field emission-scanning electron microscopy images of bulk $\mathrm{Ag}_{2} \mathrm{O}$. Figure S6. Optical images of zone of inhibition assay for (a) negative control, (b) pristine $\mathrm{MgAl}$-citrate $\mathrm{LDH}$, (c) bulk $\mathrm{Ag}_{2} \mathrm{O}$, (d) SONP@LDH-1, (e) SONP@LDH-1/3 and (f) SONP@LDH-1/10 containing paper on LB agar plates incubated at $37^{\circ} \mathrm{C} 24 \mathrm{~h}$. Each paper is $6 \mathrm{~mm}$ in diameter. Figure S7. Optical images of colony-forming unit test assay for (a) negative control, (b) pristine $\mathrm{MgAl}$-citrate $\mathrm{LDH}$, (c) bulk $\mathrm{Ag}_{2} \mathrm{O}$, (d) SONP@LDH-1, (e) SONP@LDH-1/3 and (f) SONP@LDH-1/10 on LB agar plates incubated at $37^{\circ} \mathrm{C}, 24 \mathrm{~h}$.

Author Contributions: Conceptualization, J.-M.O.; methodology, D.-G.J.; software, D.-G.J. and M.L.; validation, D.-G.J.; formal analysis, D.-G.J.; investigation, D.-G.J.; resources, J.-M.O. and S.-M.P.; data curation, D.-G.J. and M.L.; writing-original draft preparation, D.-G.J.; writing-review and editing, J.-M.O. and S.-M.P.; visualization, D.-G.J.; and M.L.; supervision, J.-M.O.; project administration, J.-M.O.; funding acquisition, J.-M.O. All authors have read and agreed to the published version of the manuscript.

Funding: This research was supported by Basic Science Research Program through the National Research Foundation of Korea(NRF) funded by the Ministry of Science, ICT and Future Planning (NRF-2017R1A2B4006352) and Following are results of a study on the "Leaders in INdustry-university Cooperation+" Project, supported by the Ministry of Education and National Research Foundation of Korea. 
Data Availability Statement: The data presented in this study are available on request from the corresponding author.

Conflicts of Interest: The authors declare no conflict of interest. And The funders had no role in the design of the study; in the collection, analyses, or interpretation of data; in the writing of the manuscript, or in the decision to publish the results.

\section{References}

1. Haq, S.; Rehman, W.; Waseem, M.; Meynen, V.; Awan, S.U.; Saeed, S.; Iqbal, N. Fabrication of pure and moxifloxacin functionalized silver oxide nanoparticles for photocatalytic and antimicrobial activity. J. Photochem. Photobiol. B Biol. 2018, 186, 116-124. [CrossRef]

2. Varkey, A.; Fort, A. Some optical properties of silver peroxide $(\mathrm{AgO})$ and silver oxide $\left(\mathrm{Ag}_{2} \mathrm{O}\right)$ films produced by chemical-bath deposition. Sol. Energy Mater. Sol. Cells 1993, 29, 253-259. [CrossRef]

3. Jo, J.; Cho, S.-P.; Lim, J.K. Template synthesis of hollow silver hexapods using hexapod-shaped silver oxide mesoparticles. J. Colloid Interface Sci. 2015, 448, 208-214. [CrossRef] [PubMed]

4. Liang, Y.-C.; Liu, Y.-C.; Hung, C.-S. Sputtering control of $\mathrm{Ag}_{2} \mathrm{O}$ decoration configurations on $\mathrm{ZnO}$ nanorods and their surface arrangement effects on photodegradation ability toward methyl orange. Nanotechnology 2019, 30, 495701. [CrossRef]

5. Chen, L.; Hua, H.; Yang, Q.; Hu, C. Visible-light photocatalytic activity of $\mathrm{Ag}_{2} \mathrm{O}$ coated $\mathrm{Bi}_{2} \mathrm{WO}_{6}$ hierarchical microspheres assembled by nanosheets. Appl. Surf. Sci. 2015, 327, 62-67. [CrossRef]

6. Yu, C.; Zhou, W.; Jimmy, C.Y.; Liu, H.; Wei, L. Design and fabrication of heterojunction photocatalysts for energy conversion and pollutant degradation. Chin. J. Catal. 2014, 35, 1609-1618. [CrossRef]

7. Hsu, M.-H.; Chang, C.-J. Ag-doped ZnO nanorods coated metal wire meshes as hierarchical photocatalysts with high visible-light driven photoactivity and photostability. J. Hazard. Mater. 2014, 278, 444-453. [CrossRef] [PubMed]

8. Du, Y.; Tang, D.; Zhang, G.; Wu, X. Facile synthesis of $\mathrm{Ag}_{2} \mathrm{O}-\mathrm{TiO}_{2}$ / sepiolite composites with enhanced visible-light photocatalytic properties. Chin. J. Catal. 2015, 36, 2219-2228. [CrossRef]

9. Galante, M.T.; Sotelo, P.; Hossain, M.K.; Vali, A.; Raamann, A.; Longo, C.; Macaluso, R.T.; Rajeshwar, K. Silver Oxide-Based Semiconductors for Solar Fuels Production and Environmental Remediation: A Solid-State Chemistry Approach. ChemElectroChem 2019, 6, 87-96. [CrossRef]

10. Gallardo, O.A.D.; Moiraghi, R.; Macchione, M.A.; Godoy, J.A.; Pérez, M.A.; Coronado, E.A.; Macagno, V.A. Silver oxide particles/silver nanoparticles interconversion: Susceptibility of forward/backward reactions to the chemical environment at room temperature. RSC Adv. 2012, 2, 2923-2929. [CrossRef]

11. Noyes, A.; Kohr, D. The Solubility Equilibrium Between Silver Chloride, Silver Oxide, and Solutions of Potassium Chloride and Hydroxide. J. Am. Chem. Soc. 1902, 24, 1141-1148. [CrossRef]

12. Banerjee, S.; Maity, A.; Chakravorty, D. Quantum confinement effect in heat treated silver oxide nanoparticles. J. Appl. Phys. 2000, 87, 8541-8544. [CrossRef]

13. Satyanarayana, N.; Xie, X.; Rambabu, B. Sol-gel synthesis and characterization of the $\mathrm{Ag}_{2} \mathrm{O}-\mathrm{SiO}_{2}$ system. Mater. Sci. Eng. B 2000, 72, 7-12. [CrossRef]

14. Ranjith, K.S.; Castillo, R.B.; Sillanpaa, M.; Kumar, R.T.R. Effective shell wall thickness of vertically aligned ZnO-ZnS core-shell nanorod arrays on visible photocatalytic and photo sensing properties. Appl. Catal. B-Environ. 2018, 237, 128-139. [CrossRef]

15. Ranjith, K.; Saravanan, P.; Vinod, V.T.P.; Filip, J.; Černík, M.; Kumar, R.R. $\mathrm{Ce}_{2} \mathrm{~S}_{3}$ decorated ZnO-ZnS core-shell nanorod arrays: Efficient solar-driven photocatalytic properties. Catal. Today 2016, 278, 271-279. [CrossRef]

16. Wang, X.; Wu, H.-F.; Kuang, Q.; Huang, R.-B.; Xie, Z.-X.; Zheng, L.-S. Shape-dependent antibacterial activities of Ag $2 \mathrm{O}$ polyhedral particles. Langmuir 2010, 26, 2774-2778. [CrossRef] [PubMed]

17. Rajabi, A.; Ghazali, M.J.; Mahmoudi, E.; Baghdadi, A.H.; Mohammad, A.W.; Mustafah, N.M.; Ohnmar, H.; Naicker, A.S. Synthesis, characterization, and antibacterial activity of $\mathrm{Ag}_{2} \mathrm{O}$-loaded polyethylene terephthalate fabric via ultrasonic method. Nanomaterials 2019, 9, 450. [CrossRef]

18. Eremenko, A.M.; Petrik, I.S.; Smirnova, N.P.; Rudenko, A.V.; Marikvas, Y.S. Antibacterial and antimycotic activity of cotton fabrics, impregnated with silver and binary silver/copper nanoparticles. Nanoscale Res. Lett. 2016, 11, 28. [CrossRef] [PubMed]

19. Kim, M.-J.; Cho, Y.-S.; Park, S.-H.; Huh, Y.-D. Facile synthesis and fine morphological tuning of $\mathrm{Ag}_{2} \mathrm{O}$. Cryst. Growth Des. 2012, 12, 4180-4185. [CrossRef]

20. Ma, S.; Xue, J.; Zhou, Y.; Zhang, Z. Photochemical synthesis of $\mathrm{ZnO} / \mathrm{Ag}_{2} \mathrm{O}$ heterostructures with enhanced ultraviolet and visible photocatalytic activity. J. Mater. Chem. A 2014, 2, 7272-7280. [CrossRef]

21. Kadam, A.; Dhabbe, R.; Gophane, A.; Sathe, T.; Garadkar, K. Template free synthesis of ZnO/Ag-O nanocomposites as a highly efficient visible active photocatalyst for detoxification of methyl orange. J. Photochem. Photobiol. B Biol. 2016, 154, 24-33. [CrossRef] [PubMed]

22. Boopathi, S.; Gopinath, S.; Boopathi, T.; Balamurugan, V.; Rajeshkumar, R.; Sundararaman, M. Characterization and antimicrobial properties of silver and silver oxide nanoparticles synthesized by cell-free extract of a mangrove-associated Pseudomonas aeruginosa M6 using two different thermal treatments. Ind. Eng. Chem. Res. 2012, 51, 5976-5985. [CrossRef]

23. Ahmad, T.; Wani, I.A.; Al-Hartomy, O.A.; Al-Shihri, A.S.; Kalam, A. Low temperature chemical synthesis and comparative studies of silver oxide nanoparticles. J. Mol. Struct. 2015, 1084, 9-15. [CrossRef] 
24. Rutberg, F.; Dubina, M.; Kolikov, V.; Moiseenko, F.; Ignat'eva, E.; Volkov, N.; Snetov, V.; Stogov, A.Y. Effect of silver oxide nanoparticles on tumor growth in vivo. Dokl. Biocehm. Biophys. 2008, 421, 191-193. [CrossRef] [PubMed]

25. He, J.; Ichinose, I.; Fujikawa, S.; Kunitake, T.; Nakao, A. Reversible conversion of nanoparticles of metallic silver and silver oxide in ultrathin $\mathrm{TiO}_{2}$ films: A chemical transformation in nano-space. Chem. Commun. 2002, 1910-1911. [CrossRef] [PubMed]

26. Singh, P.; Parent, K.L.; Buttry, D.A. Electrochemical solid-state phase transformations of silver nanoparticles. J. Am. Chem. Soc. 2012, 134, 5610-5617. [CrossRef] [PubMed]

27. Gao, A.; Hang, R.; Huang, X.; Zhao, L.; Zhang, X.; Wang, L.; Tang, B.; Ma, S.; Chu, P.K. The effects of titania nanotubes with embedded silver oxide nanoparticles on bacteria and osteoblasts. Biomaterials 2014, 35, 4223-4235. [CrossRef] [PubMed]

28. Cavani, F.; Trifiro, F.; Vaccari, A. Hydrotalcite-type anionic clays: Preparation, properties and applications. Catal. Today 1991, 11, 173-301. [CrossRef]

29. Khan, A.I.; O'Hare, D. Intercalation chemistry of layered double hydroxides: Recent developments and applications. J. Mater. Chem. 2002, 12, 3191-3198. [CrossRef]

30. Choy, J.-H.; Jung, J.-S.; Oh, J.-M.; Park, M.; Jeong, J.; Kang, Y.-K.; Han, O.-J. Layered double hydroxide as an efficient drug reservoir for folate derivatives. Biomaterials 2004, 25, 3059-3064. [CrossRef] [PubMed]

31. Choy, J.-H.; Choi, S.-J.; Oh, J.-M.; Park, T. Clay minerals and layered double hydroxides for novel biological applications. Appl. Clay Sci. 2007, 36, 122-132. [CrossRef]

32. Oh, J.-M.; Choi, S.-J.; Kim, S.-T.; Choy, J.-H. Cellular uptake mechanism of an inorganic nanovehicle and its drug conjugates: Enhanced efficacy due to clathrin-mediated endocytosis. Bioconjugate Chem. 2006, 17, 1411-1417. [CrossRef] [PubMed]

33. Xu, Z.P.; Zhang, J.; Adebajo, M.O.; Zhang, H.; Zhou, C. Catalytic applications of layered double hydroxides and derivatives. Appl. Clay Sci. 2011, 53, 139-150. [CrossRef]

34. Gunjakar, J.L.; Kim, T.W.; Kim, H.N.; Kim, I.Y.; Hwang, S.-J. Mesoporous layer-by-layer ordered nanohybrids of layered double hydroxide and layered metal oxide: Highly active visible light photocatalysts with improved chemical stability. J. Am. Chem. Soc. 2011, 133, 14998-15007. [CrossRef]

35. Chen, C.-R.; Zeng, H.-Y.; Yi, M.-Y.; Xiao, G.-F.; Zhu, R.-L.; Cao, X.-J.; Shen, S.-G.; Peng, J.-W. Fabrication of Ag 2 O/Ag decorated $\mathrm{ZnAl}$-layered double hydroxide with enhanced visible light photocatalytic activity for tetracycline degradation. Ecotox. Environ. Safe. 2019, 172, 423-431. [CrossRef] [PubMed]

36. Henglein, A.; Giersig, M. Formation of colloidal silver nanoparticles: Capping action of citrate. J. Phys. Chem. B. 1999, 103, 9533-9539. [CrossRef]

37. Rives, V.; del Arco, M.; Martín, C. Intercalation of drugs in layered double hydroxides and their controlled release: A review. Appl. Clay Sci. 2014, 88, 239-269. [CrossRef]

38. Kang, H.; Kim, H.-J.; Yang, J.-H.; Kim, T.-H.; Choi, G.; Paek, S.-M.; Choi, A.-J.; Choy, J.-H.; Oh, J.-M. Intracrystalline structure and release pattern of ferulic acid intercalated into layered double hydroxide through various synthesis routes. Appl. Clay Sci. 2015, 112, 32-39. [CrossRef]

39. Ruparelia, J.P.; Chatterjee, A.K.; Duttagupta, S.P.; Mukherji, S. Strain specificity in antimicrobial activity of silver and copper nanoparticles. Acta Biomater. 2008, 4, 707-716. [CrossRef] [PubMed]

40. Shao, W.; Liu, X.; Min, H.; Dong, G.; Feng, Q.; Zuo, S. Preparation, characterization, and antibacterial activity of silver nanoparticledecorated graphene oxide nanocomposite. ACS Appl. Mater. Interfaces 2015, 7, 6966-6973. [CrossRef]

41. Goderecci, S.S.; Kaiser, E.; Yanakas, M.; Norris, Z.; Scaturro, J.; Oszust, R.; Medina, C.D.; Waechter, F.; Hoen, M.; Krchnavek, R.R.; et al. Silver oxide coatings with high silver-ion elution rates and characterization of bactericidal activity. Molecules 2017, $22,1487$. [CrossRef] [PubMed]

42. Oh, J.-M.; Hwang, S.-H.; Choy, J.-H. The effect of synthetic conditions on tailoring the size of hydrotalcite particles. Solid State Ion. 2002, 151, 285-291. [CrossRef]

43. Bragg, W.L. The diffraction of shrot electromagnetic waves by a crystal. In Proceedings of the Cambridge Philosophical Society, Cambridge, UK, 14 February 1913; pp. 43-57.

44. Tronto, J.; dos Reis, M.J.; Silvério, F.; Balbo, V.R.; Marchetti, J.M.; Valim, J.B. In vitro release of citrate anions intercalated in magnesium aluminium layered double hydroxides. J. Phys. Chem. Solids 2004, 65, 475-480. [CrossRef]

45. Padma Kumar, P.; Kalinichev, A.G.; Kirkpatrick, R.J. Hydration, swelling, interlayer structure, and hydrogen bonding in organolayered double hydroxides: Insights from molecular dynamics simulation of citrate-intercalated hydrotalcite. J. Phys. Chem. B 2006, 110, 3841-3844. [CrossRef]

46. Djokić, S. Synthesis and antimicrobial activity of silver citrate complexes. Bioinorg. Chem. Appl. 2008, 2008. [CrossRef] [PubMed]

47. Ananth, A.; Mok, Y.S. Dielectric barrier discharge (DBD) plasma assisted synthesis of $\mathrm{Ag}_{2} \mathrm{O}$ nanomaterials and $\mathrm{Ag}_{2} \mathrm{O} / \mathrm{RuO}_{2}$ nanocomposites. Nanomaterials 2016, 6, 42. [CrossRef]

48. Ravichandran, S.; Paluri, V.; Kumar, G.; Loganathan, K.; Kokati Venkata, B.R. A novel approach for the biosynthesis of silver oxide nanoparticles using aqueous leaf extract of Callistemon lanceolatus (Myrtaceae) and their therapeutic potential. J. Exp. Nanosci. 2016, 11, 445-458. [CrossRef]

49. Choi, S.-W.; Katoch, A.; Sun, G.-J.; Wu, P.; Kim, S.S. $\mathrm{NO}_{2}$-sensing performance of $\mathrm{SnO}_{2}$ microrods by functionalization of Ag nanoparticles. J. Mater. Chem. C 2013, 1, 2834-2841. [CrossRef]

50. Diehm, P.M.; Ágoston, P.; Albe, K. Size-dependent lattice expansion in nanoparticles: Reality or anomaly? ChemPhysChem 2012, 13, 2443-2454. [CrossRef] [PubMed] 
51. Ashokraja, C.; Sakar, M.; Balakumar, S. A perspective on the hemolytic activity of chemical and green-synthesized silver and silver oxide nanoparticles. Mater. Res. Express 2017, 4, 105406. [CrossRef]

52. Cullity, B. Elements of X-Ray Diffraction; Addion-Wesley Publishers: Boston, MA, USA, 1978.

53. Nist X-Ray Photoelectron Spectroscopy Database; Version 4.1; National Institute of Standards and Technology: Gaithersburg, MD, USA, 2012

54. Hoflund, G.B.; Hazos, Z.F.; Salaita, G.N. Surface characterization study of Ag, AgO, and $\mathrm{Ag}_{2} \mathrm{O}$ using x-ray photoelectron spectroscopy and electron energy-loss spectroscopy. Phys. Rev. B 2000, 62, 11126. [CrossRef]

55. Yuan, Z.; Yang, H.; Xu, P.; Li, C.; Jian, J.; Zeng, J.; Zeng, L.; Sui, Y.; Zhou, H. Facile in situ synthesis of silver nanocomposites based on cellulosic paper for photocatalytic applications. Environ. Sci. Pollut. Res. 2020, 1-11. [CrossRef] [PubMed]

56. Wang, X.; Li, S.; Yu, H.; Yu, J.; Liu, S. $\mathrm{Ag}_{2} \mathrm{O}$ as a new visible-light photocatalyst: Self-stability and high photocatalytic activity. Chem. Eur. J. 2011, 17, 7777-7780. [CrossRef] [PubMed]

57. Xu, M.; Han, L.; Dong, S. Facile fabrication of highly efficient g- $\mathrm{C}_{3} \mathrm{~N}_{4} / \mathrm{Ag}_{2} \mathrm{O}$ heterostructured photocatalysts with enhanced visible-light photocatalytic activity. ACS Appl. Mater. Iinterfaces 2013, 5, 12533-12540. [CrossRef]

58. Makuła, P.; Pacia, M.; Macyk, W. How to correctly determine the band gap energy of modified semiconductor photocatalysts based on UV-Vis spectra. J. Phys. Chem. Lett. 2018, 9, 6814-6817. [CrossRef]

59. Baskoutas, S.; Terzis, A.F. Size-dependent band gap of colloidal quantum dots. J. Appl. Phys. 2006, 99, 013708. [CrossRef]

60. Li, M.; Li, J. Size effects on the band-gap of semiconductor compounds. Mater. Lett. 2006, 60, 2526-2529. [CrossRef]

61. Lin, K.-F.; Cheng, H.-M.; Hsu, H.-C.; Lin, L.-J.; Hsieh, W.-F. Band gap variation of size-controlled ZnO quantum dots synthesized by sol-gel method. Chem. Phys. Lett. 2005, 409, 208-211. [CrossRef]

62. Qiu, J.-H.; Zhou, P.; Gao, X.-Y.; Yu, J.-N.; Wang, S.-Y.; Li, J.; Zheng, Y.-X.; Yang, Y.-M.; Song, Q.-H.; Chen, L.-Y. Ellipsometric study of the optical properties of silver oxide prepared by reactive magnetron sputtering. J. Korean Phys. Soc. 2005, 46, 269.

63. Morpurgo, S.; Jacono, M.L.; Porta, P. Pillared hydroxycarbonates and mixed oxides. Part 1.-Copper-zinc-cobalt-aluminium system. J. Mater. Chem. 1994, 4, 197-204. [CrossRef]

64. Kim, S.J.; Lee, Y.; Lee, D.K.; Lee, J.W.; Kang, J.K. Efficient Co-Fe layered double hydroxide photocatalysts for water oxidation under visible light. J. Mater. Chem. A 2014, 2, 4136-4139. [CrossRef]

65. Parida, K.; Satpathy, M.; Mohapatra, L. Incorporation of $\mathrm{Fe}^{3+}$ into $\mathrm{Mg} / \mathrm{Al}$ layered double hydroxide framework: Effects on textural properties and photocatalytic activity for $\mathrm{H}_{2}$ generation. J. Mater. Chem. 2012, 22, 7350-7357. [CrossRef]

66. Prabhu, S.; Poulose, E.K. Silver nanoparticles: Mechanism of antimicrobial action, synthesis, medical applications, and toxicity effects. Int. Nano Lett. 2012, 2, 1-10. [CrossRef]

67. Liau, S.Y.; Read, D.C.; Pugh, W.J.; Furr, J.R.; Russell, A.D. Interaction of silver nitrate with readily identifiable groups: Relationship to the antibacterialaction of silver ions. Lett. Appl. Microbiol. 1997, 25, 279-283. [CrossRef]

68. Ishida, T. Antibacterial mechanism of $\mathrm{Ag}^{+}$ions for bacteriolyses of bacterial cell walls via peptidoglycan autolysins, and DNA damages. MOJ Toxicol. 2018, 4, 345-350. [CrossRef]

69. Gordon, O.; Slenters, T.V.; Brunetto, P.S.; Villaruz, A.E.; Sturdevant, D.E.; Otto, M.; Landmann, R.; Fromm, K.M. Silver coordination polymers for prevention of implant infection: Thiol interaction, impact on respiratory chain enzymes, and hydroxyl radical induction. Antimicrob. Agents Chemother. 2010, 54, 4208-4218. [CrossRef] [PubMed]

70. Russell, A.D.; Hugo, W.B. Chapter 7-antimicrobial activity and action of silver. In Progress in Medicinal Chemistry; Elsevier: Amstredam, The Netherlands, 1994. [CrossRef] 